Vol. 12 (2): 371-376 (2022)

\title{
HISTORICAL GENESIS OF THE DEVELOPMENT OF CRIMINALISTICS IN THE CONTEXT OF NATURAL AND TECHNICAL SCIENCES
}

\author{
Sharap Seitkasymovich Saduakassov ${ }^{1 *}$, Baurzhan Smatlayev ${ }^{1}$, Yerazak Manapovich Tileubergenov ${ }^{2}$, \\ Saule Zhusupbekovna Seitenova ${ }^{2}$, Igor Vladimirovich Ossyko ${ }^{3}$ \\ ${ }^{1 *}$ L.N. Gumilyov Eurasian National University, Republic of Kazakhstan; \\ ${ }^{2}$ Kokshetau University named after Sh.Ualikhanov, Republic of Kazakhstan; \\ ${ }^{3}$ Kokshetau University named after Abai Myrzakhmetov, Republic of Kazakhstan;
}

*Corresponding Author Sharap Seitkasymovich Saduakassov, email: ekaterina.a.vetrova@mail.ru;

Received December 2021; Accepted January 2022; Published February 2022;

DOI: https://doi.org/10.31407/ijees12.208

\begin{abstract}
In this study, the authors reveal the genesis of the emergence, development and transformation of applied criminology through the prism of natural and technical sciences. It is noted that science and technology in the detection and investigation of crimes is a problem that has been and remains one of the key throughout the history of society's counteraction to such a social phenomenon as crime. This problem has been noticeably actualized in the conditions of scientific and technological progress, the achievements of which are equally used by people striving for noble, socially significant goals and pursuing their own selfish, criminal interests. That is why it is so important to trace the genesis and reveal the essence of criminology within the framework of the natural and technical sciences. This problem becomes particularly acute at the "critical" stages of the development of society, in conditions of crisis socio-economic situations, the formation of new socio-economic relations.
\end{abstract}

Key words: criminalistics, genesis of development, natural sciences, technical sciences, legal science. 